\title{
Reexamining the UNCLOS: a Lack of Compliance and Enforceability
}

\section{Kishore Vaangal*}

Vaangal, K. (2022). Reexamining the UNCLOS: a Lack of Compliance and Enforceability. Lex Portus, 8(1), 7-27. https://doi.org/10.26886/2524-101X.8.1.2022.1

*PhD, Alagappa University (Karaikudi 630003, Tamil Nadu, India) https://orcid.org/0000-0001-5447-0962 (c) 13 This work is licensed under a Creative Commons Attribution-

\section{ABSTRACT}

The article examines the effeteness of UNCLOS and espouses on why it is not a De Jure legally binding agreement but a De facto non-binding agreement. The uncertainty in the law of the sea would inevitably grow and increasingly State practice, across geographies, may well continue to diverge from the traditional views of the law. Given that states are increasingly under the influence of domestic politics and racial tensions, divergence per se is inevitable, and the dire need of the hour is for the comity of nations to get their act together, vis a vis, re-examining the UNCLOS agreement and to thereafter usher in an agreement that would work. The need to rewrite would require much effort and the cooperation of all the states and indubitably, it would call for egalitarian approaches.

The keywords: law of the seas, Constitution of the Seas, maritime jurisprudence, the one ocean concept, the binding nature, interpretations of UNCLOS, International Law, USA, China. 


\section{Introduction}

Thirty-nine years ago, in circa 1982, raw optimism could have prevailed upon the assemblage of diplomats in that they conceived of a legal order for the oceans which will promote the peaceful uses of the seas and oceans, the conservation of their living resources and the preservation of the marine environment. Sardonically, the thirtynine years that have passed by makes for one glaring observation in that the UNCLOS has clearly and comprehensively failed to achieve its goals and objectives. A grave reason for the same is due to the continuing non-compliance, by many member states, with many of its provisions, and as facts are stubborn things, would the non-compliance not tantamount to the non-binding nature of its provisions? ${ }^{1}$ Even if zealots were to articulate on the basis of the VCLT, it should be seen by any unbiased researcher as de facto nonbinding - in effect, even if UNCLOS is recognized as binding law, the practices of non-compliance and unenforceability that exist in reality would make it out to be a de facto non-binding agreement. As a matter that upholds the finer nuances of jurisprudence, apropos the law of contracts, issues that make the contract unenforceable would result in void agreements and this is an axiomatic inference (Churchill, 2012). Ejusdem Generis, with the UNCLOS as can be deciphered by the empirical evidence that even after 63 years after UNCLOS I and 39 years after UNCLOS III, there are significantly consistent pattens of non-compliance and effete enforceability.

\section{Is the UNCLOS is dysfunctional?}

Even a perfunctory examination, vis a vis, the actions of P5 (the five permanent members of the UN Security Council with plenary veto powers) Member States would establish that the UNCLOS is indeed a faulty Constitution of the Seas and any member state must

1 The Doctrine of Rational Expectations, a percept that has its origins in philosophy, is a rule that the realms of jurisprudence and the economic science have borrowed, and in effect, it is based on pragmatic overtures akin to real experiences and the like. 
be very suspicious of assertive premises, such as, given the fact that it is an international agreement, other member states would naturally accede to the tenets it espouses. The illustration centred on the P 5 (the United States and China in particular) will prove beyond any doubt whatsoever that UNCLOS per se has done nothing of substance to appositely and pragmatically streamline international maritime jurisprudence in an equitable manner, and in fact, it could be deciphered, albeit ironically that the converse is the reality of the day. The rule of law, with reference to the seas has certainly not been established by UNCLOS and even a plain reading of the text of the UNCLOS agreement would establish that nowhere in the text of the agreement has the word BINDING been emphatically emphasised, and as such, it can be inferentially deduced that the signatories did not intend it to make it comprehensively binding as such. The proof of a pudding lies in eating it and given that some scholars have vouched for UNCLOS to have streamlined (largely to suit conveniences) customary international law, it does not have tenable standing (a core requirement of acceptable international law) as can be viewed from the fact that even on a core issue like the EEZ, there has been a faux pas in that via extending the claims of coastal states far into the sea, well beyond the traditional claims that had existed for centuries, UNCLOS was clearly in contradistinction with accepted customary law. The newer claims and conflicts are at the heart of much disagreement and disharmony and this has led to much discord and disarray with member states openly violating its extant provisions and UNCLOS has not had the verve to bring the culprits to book (Van Deutekom, 2016). UNCLOS is a bad idea, badly conceived and effetely effectuated on and as factual research has laid bare, it has done hardly anything to stymie the kind of maritime terrorism that is just waiting to happen, and the day is not far off when a stateless actor would in actuality eventuate on the heinous act of blowing up an offshore Deepsea rig and literally get away scot free thereafter, with regard to providing for just recompense (Vaangal, 2021). 
The United Nations Convention on the Law of the Sea, confined to its signatories, indeed gets to ideate on the right of member states, and this includes four permanent members of the Security Council ${ }^{1}$. Whilst the convention has been signed by well over 150 countries, even amongst the permanent members of the Security Council, they have had a pick and choose format under which those regulations that they seem to like are upheld and the others are comprehensively ignored. As an example China uses the nine dash line to justify vile action which any rational bystander would dub to be in contra distinction with the tenets of UNCLOS, and given that there has been no retributive action or enforceability for that matter, a seminal query would arise in that any discerning researcher worth his salt would simply ask if the UNCLOS is really a binding instrument? (Chaudhury, 2021). The obligation to exercise self-restraint and cooperate - UNCLOS Articles 74 (3) and 83 (3) have not been eventuated into reality by certain member states and the principle of good faith as espoused by Article 300 of UNCLOS hasn't been paid heed to as well. Canada, Israel, United States of America, Venezuela, and Turkey among the most prominent member states that have not ratified the UNCLOS agreement. Given the one ocean concept, how would these nations react to situations dictates, vis a vis, ecological destruction caused by the blowing up of offshore rigs in their exclusive economic zone and beyond? Therefore, as the seas and the oceans are the common heritage of mankind, even if it is premised that the UNCLOS is only marginally non-binding, and that the non-binding nature is confined to just a few geographies, it wouldn't make any sense at all as due to the inherent feature of interconnectivity, when one area is contaminated, the contamination would spread to other areas as well and this has been highlighted by the findings of the research whilst examining the Deepwater Horizon event. When enforceability per se of any agreement becomes a question, why

\footnotetext{
1 The United States of America is yet to ratify UNCLOS.
} 
would the question of its binding nature even arise, despite the fact that $\operatorname{cog}$ s in the system may go overboard with reference to enunciating on its binding nature? Additionally, just because an agreement is stipulated to be binding, when glaring omissions and commissions are committed by some of the signatories and subscribers, and when zilch enforceability, vis a vis, the high and mighty, ensues despite the relevant dispute and settlement clauses, how can any sane researcher dub it as a binding agreement? ${ }^{1}$ Hindsight 2020, when UNCLOS was originally conceived in circa 1958, it was meant to codify and streamline the principles of International Maritime Jurisprudence that were based on the experiences of the past, the UN Charter and the Geneva Convention of circa 1958. The bottom line being that UNCLOS was meant to explicate on the rights, duties and obligations of member states apropos the usage and governance of the seas and the oceans. Sixtythree years after UNCLOS I and thirty-nine years after UNCLOS III, UNCLOS has clearly failed to achieve these goals and this is largely due to the blatant and continuing non-compliance of many of its provisions et al. When it has been clearly established that UNCLOS has utterly failed to achieve its goals due to noncompliance by many states, leading also to effete enforceability, how could it be defined to be legally binding? Given that profligacy apropos compliance and effeteness apropos enforceability have characterized the functionality of UNCLOS, member states of the UNO like the United States and China have gotten away scot-freeperhaps, the first amongst equals syndrome that is obvious should in itself be suggestive of the fact that a pick-and choose system of upholding the tenets of UNCLOS is at play, and several coastal states, when their authorities were interviewed, simply stated that

1 Whilst it has been articulated that the decisions of ITLOS would need to be legally binding, the many sore issues highlighted by this article have indeed showcased how in reality they have been non-binding - http://www.unclosdebate.org - hence, postulating ... that verdicts of UNCLOS dispute settlement mechanism are always legally binding would raise more questions than answers et al. 
UNCLOS far from being the constitution of the seas has proven to be a very inequitable instrument ${ }^{1}$. It all depends on which side of the fence the researcher is in - if he is from a developing nation, he would, should he be worth his salt, resort to the kind of analysis that $I$ have engaged in and if he is from a P 5 or a $G 5$ nation, the analysis would veer towards ideating as to why a pick-andchoose method is apposite as it is also in consonance with their respective constitutions ${ }^{2}$. In fact, as old as jurisprudence itself is the juxtaposition of the de jure and de facto positions, and though some academicians and members of the establishment can nomenclature UNLOS as a de jure binding agreement, this research initiative has lucidly espoused on why its effeteness and non-enforceability, vis a vis, certain crucial areas would make it out to be a de facto nonbinding agreement (Bateman, 2009).

\section{Exploring the Binding Nature of UNCLOS}

The arguments centric to the binding nature of UNCLOS almost always hovers around accession and the adherents equate it to behaviour patterns that are conducive and as diplomacy is often ensuring that the member state in question has a seat at the table, many core issues that does not affect that particular member state are often overlooked. Both China and the United States have had a pick and choose policy, vis a vis, abiding with UNCLOS regulations and the US in fact is not even a signatory despite being a permanent member (with plenary vetoing powers) in the UN Security Council (Almond, 2017). China, is a signatory no doubt, but has acted like a central villain and has bastardized the UNCLOS regime no end

1 On a core issue of signification centric to the International Seabed Authority and though the United States is still to ratify UNCLOS, the matter is being specially mentioned as the permanent members of the Security Council are meant to lead by upholding good and progressive principles - instead, they have all driven hard bargains from dominant positions.

2 The United States example, vis a vis, the International Seabed Authority, being a classic case in point. 
as it has worked against the core stipulations (Some Irresponsible Nations Twisting Definition Of UNCLOS: Rajnath Singh's Veiled Dig At China). Indeed China's actions 'speak' so much 'for the binding nature of UNCLOS,' and given the fact that DESPITE the vile actions of a permanent member, UNCLOS has been unable to do anything via any of its mechanisms, it only proves and establishes that the text of the agreement just comprises of words and more words ... that have not much pragmatic signification. A violation by a powerful member would simply mean that the authorities will be forced to look the other way after making some perfunctory utterances ... et alia $^{1}$. Even at the home of maritime law, the United Kingdom, there has been a committee of inquiry that has been set up to gauge the efficacity of UNCLOS as there was serious disgruntlement, vis a vis, enforcement issues, the verve of its dispute settlement mechanisms, and matters to do with UNCLOS' capabilities centric to handling climate change challenges, autonomous maritime systems and security at sea ${ }^{2}$. Optional declarations under Article 287 of UNCLOS with certitude increases the state's use of non-binding methods of dispute settlement and such issues provide for much leeway for surreptitious play (Mitchell \& Owsiak, 2021).

As an addendum, the bare text of the UNCLOS Agreement has not been emphatic when using the word binding in its seventeen parts and nine annexures. No wonder that China has used and very deftly at that its very own conception of UNCLOS and by bulldozing its way through VIA the might is right philosophy, it has blatantly made a mockery of the regulations of UNCLOS and no concrete action has been taken against a prime permanent member. Russia and France have also used the tenets of UNCLOS to suit conveniences (Karev, 1995).

\footnotetext{
1 Et alia is a Latin expression that the jurisprudential realms have borrowed and in effect it means ... and others.

2 See: UNCLOS: fit for purpose in the 21st century? UK Parliament. https:/committees.parliament.uk/work/1557/unclos-fit-for-purpose-in-the-21st-century/
} 
For the French and the EU position, trade interests supersede the UNCLOS ruling per se. So much for the perceived binding nature of UNCLOS that scores of scholars and diplomats have referred to it in order to suit their conveniences and fancies. In the 63 years of UNCLOS, on several occasions, the rich and powerful nations have gotten away scot-free after contemptuously disregarding UNCLOS regulations, and even a 101 research exercise will simply establish the pragmatic signification - that the regulations are indeed significantly non-binding and that they are just nothing more than idealized portrayals of what the regulations ought to be. In this section, I will confine myself primarily to the acts of permanent members as that would make the point, vis a vis, the non-binding nature in a most telling and pragmatic way. The definition of a legally binding agreement is simple - it needs to be irrevocable, unalterable, unbreakable, indissoluble, permanent, compulsory, obligatory, imperative, mandatory, necessary, conclusive, signed and delivered and sanctioned by law and enforceable. Given the inactions and actions of the United States and China, two permanent members, by no stretch of any researcher's imagination, can the UNCLOS be called binding (Schrepferman, 2019). Their actions or the lack of it have made the binding nature of UNCLOS look preposterous. Another glaring exemplar, vis a vis, China, is its venal interpretation of UNCLOS, and this has specific consequences for the offshore rig verticals in that China has assumed rights far beyond what has been stipulated by UNCLOS, and on no account, could the drafters of UNCLOS ever conceived of such bizarre interpretations. There are several economic and security issues that have cropped up in the South China Sea and the area can literally be compared to a Don's den and had some poor nation engaged in such exercises, the entire UN establishment, inclusive of UNCLOS, would have been up in arms against that nation. Hence, it could be stated sagaciously that UNCLOS is indeed binding for the poorer countries (member states that are signatories) but not so for the rich 
and powerful nations that are permanent members of the security council (Kapoor, 2021) ${ }^{1}$. The pick and choose policy of the US (albeit being a non-signatory) and China has clearly demonstrated the non-binding nature of UNCLOS. China's fabricated rights and the stance of the United States, vis a vis, the International Seabed Authority are two sore examples amongst the many that make the permanent members to be first amongst equals (Bandow, 1982). Given that numerous adherents have always articulated that UNCLOS is binding legally and that it is a Bona fide instrument in International Law that 158 countries have signed and ratified, the research initiative that I have engaged in simply points to the fact that this widespread recognition of these made-up rights has been the death knell of the freedom of the seas, and not its enablement and this is simply because of the pick-and choose attitude of certain powerful members, who have, by their actions debunked the rightsduties-obligations equation of UNCLOS. Whilst the UNCLOS could be stated to be binding for some poorer and lesser developed member states, the disputes and settlement mechanism can do little against certain member states that are rich, powerful and have all the clout to either engineer a verdict in their favour or to ignore it all together. In fact, a sensible assessment of the workings of DOLAS (Division of Ocean Affairs and Law of the Sea) would reveal that the civil servants working at DOLAS did do whatever it took to make UNCLOS out to be an egalitarian agreement, but the actions of the powerful member states have in actuality made the treaty to be effete and to that extent a de facto non-binding agreement. When member states have raised for various vested reasons, the ante of EEZ rights (it has become a sore and problematical issue), they have, in effect, queried the binding nature of UNCLOS and the Chinese events of recent vintage have more than highlighted the issue. China speaks an unequivocally less aggressive language but acts in a most

1 Russia's calibrated support of China' stance in actuality makes a mockery of the UNCLOS ruling per se. 
reprehensibly aggressive way and flouts the tenets of UNCLOS blatantly and despite the actions of two permanent members of the security council - the US not ratifying UNCLOS on account of the ISA and concomitant issues, and the Chinese rowdiness on the EEZ and allied issues, if any researcher worth his salt is inclined to consider the UNCLOS as a binding legal instrument, it would be very obvious that the researcher is either unnuanced in the aforementioned or is simply playing up to the higher echelons of academia (Bromund et al., 2018). The bastardization of UNCLOS by the powerful has driven out its good tenets and my research indicated that that it is time to call for the revocation of UNCLOS and bring forth a candid discussion apropos the One Ocean concept and the other areas that UNCLOS was purported to have covered. The role of International Law has to be equitable, under every and any circumstance, and given certain rising powers, it has to have the efficacity to tame the rowdiness that has ensued and that which could get viler. Quintessentially, the rule of law that UNCLOS endeavoured to usher is a contractual matter and just as there are good and bad contracts, on the serious counts of non-compliance and the inability to effectuate comprehensive enforceability, UNCLOS has become a bad contract - therefore void per se and elemental jurisprudence would uphold that a void agreement is simply non-binding. Just to reiterate, a bad contract is void per se, but ironically in the case of UNCLOS, despite the fact that it is becoming the worst example of an international treaty, certain quarters still espouse on its binding nature. Indeed, certain vested interests are endeavouring to keep alive a deceased agreement ${ }^{1}$. The merits are debatable and colourable exercises of power are more the norm than the exception in so far as UNCLOS goes, and given the fact that a permanent member is yet to ratify it, the obligations are

1 For an insightful overview, see: Guzman, A. The Consent Problem in International Law. Berkley Law School. https://escholarship.org/content/qt04x8x174/qt04x8x174_noSplash_5221402d70d7d0b5afbb467a7a464009.pdf 
increasingly being effectuated on a pick-and-choose format. The legal system at the international level does mean that UNCLOS would become a rule of law only when it is signed and for a nonsignatory like the United States, it could count for zilch and as an addendum, given that another permanent member is endeavouring hard to redefine UNCLOS, in accord with their whims and fancies, without renegotiating the contract, in effect, its actions are not only undermining international law, they are also making a larger point of the de facto non-binding nature of UNCLOS. China and its vassal states seem to be increasingly having major differences and the issues at hand are far too substantial as the differences, if paid cognizance to, would result in a totally different agreement. In effect, UNCLOS is emblematic of a systematic disagreement and the present contest is between China and the United States, with the former endeavouring to rewrite UNCLOS and the latter protesting even without ratifying the agreement. Whilst China can be faulted for strange interpretations of UNCLOS, the United States is a stranger to the contract, and as a natural corollary of the stance of two permanent members, UNCLOS would have to be seen as a non-binding instrument that has created more confusion than anything else apropos the Law of the Seas ${ }^{1}$.

\section{Instances of the UNCLOS dysfunctionality}

It certainly cannot be called the Constitution of the Seas due to the various faux pas. It needs to be overhauled as it is de facto non-binding.

The run-of-the-mill view of several scholars and jurists. Adherents always premise that UNCLOS is quintessentially an

1 Even without ratification, UNCLOS has already achieved binding customary international law status in the US. UNCLOS debate. https://www.unclosdebate.org/evidence/737/ even-without-ratification-unclos-has-already-achieved-binding-customary-international - the article prima facie ignores the fact that it is only when the US Senate ratifies it would it become binding in the United States and a mere act of submission simply denotes that the document has been placed on the table of the United States Senate for due deliberations of merit. 
international treaty, and as such, it would be governed by the Law of Treaties - something which was espoused on by the 1969 Vienna Convention and hence, it would deemed to be reflective of customary international law, and as such, it would bind the states that ratify it $^{1}$. They go on to cite that a plethora of provisions that have been incorporated in the UNCLOS agreement, are in effect, age old rules and principles of the international law of the sea, and as a logical upshot, they are intrinsically a part of other international instruments. The aforementioned, in accordance with the view of the adherents are applicable to all states as customary law and via the subtle usage of words, they tend to make their point - in effect, by using words such as 'every state' as opposed to 'state parties,' they endeavour to make their point; nonetheless, the doctrine of reasonableness, a core paradigm that has governed jurisprudential thought since time immemorial would point to the time-tested and people-tested way, vis a vis, referring to the states that have ratified a particular treaty as 'state parties'. Apropos UNCLOS, applying the aforementioned on an Ejusdem Generis basis, states that have not ratified the agreement are as such non-parties to UNCLOS ${ }^{2}$.

The adherents have articulated that UNCLOS has established a plethora of direct and indirect responsibilities for states and this would include an adherence to advisory opinions et al, even whilst via Part $\mathrm{XV}$, the jurisdiction of international courts and tribunals

1 The adherents also premise that via $18 \mathrm{a}$ of the VCLT, even states that do not ratify, are covered to a certain extent.

2 Only a colorable interpretation would allow any researcher to consider a non-party and a non-signatory to be a deemed party to the UNCLOS Agreement, and by bringing generic declarations made by some of the states (the United States and Iran exemplars) in other forums into the purview of UNCLOS are indeed exercises in irrational exuberance. Article 310 A of UNCLOS in specificity allows states and entities to make declarations or statements regarding its application at the time of signing, ratifying or acceding to the convention, which do not purport to exclude or modify the legal effect of the provisions of the convention. This article has been misinterpreted by a number of scholars and via citing the effects of some other conventions, they have endeavored to deduce the fact that the state under consideration has in effect acceded under the aegis of Article $310 \mathrm{~A}$. As such, such deductions are fallacious exercises. 
would come into play. They often cite that the binding settlement of disputes mechanism is to be considered pathbreaking under international law ${ }^{1}$. Based on the aforementioned, they conclude that the 'legal and binding nature' of UNCLOS is not to be queried even whist conceding that the practicality of the binding nature is something that can be debated based on past events. They often go on to add that the problem is generic to international law in itself and some of the more mature scholars, amongst the group of adherents, have gone on to state that the difficulty is to ensure that States abide by the rules that they themselves have agreed to respect ${ }^{2}$. Most of them agree that UNCLOS and international law in general provide States with an array of tools, rules and procedures to stand against an act of non-compliance by another State. Nonetheless, they concede that the real problem is overall there is not much of cooperation and states do lack a full understanding of the rules and procedures ${ }^{3}$. Finally, when queried on issues to do with the permanent members and UNCLOS, they almost always draw a blank and

$A$ riposte to the run-of- the mill ideation. There is genuine reason why building knowledge, capacity and an informed dialogue through, inter alia, academic research is essential to enhance awareness apropos the fault-lines of UNCLOS and international law at large as many amongst the pro UNCLOS lobby just do not have an answer when presented with hard facts apropos violations by the permanent members of the security council. The last thing that

1 For an insightful overview on the 'binding settlement of disputes', see: Koskenniemi, M. (2006). Fragmentation of International Law: Difficulties Arising From the Diversification and Expansion of International Law: Report of the Study Group of the International Law Commission, International Law Commission Fifty-eighth session (Geneva, 1 May - 9 June and 3 July - 11 August). https://legal.un.org/ilc/documentation/english/a_cn4_1682.pdf

2 Even the most zealous of adherents, ranging from research scholars to policy makers and diplomats have acquiesced to the fact that the UNCLOS mechanism is awfully flawed on account its enforceability and non-compliance issues. The central point being that if a rule is intentionally not abided to, and when the lack of enforceability is pronounced, the system per se is plagued by its non-binding nature.

3 A Diplomat's way of making the point, vis a vis, the non-binding nature of UNCLOS. 
I want to do is to argue with 'articulate scholars' but I find it difficult to understand how one can call UNCLOS legally binding when permanent and prominent members get away scot-free on a repeated basis. If pragmatism is absent, it simply means and denotes the lack of enforceability and when a regulation or for that matter a rule of law is unenforceable (in any situation and case and against any violating member state), it cannot be dubbed any other way but the perfunctory itemization of a code of conduct. The instances that the adherents often cite have been majorly from the developing world and given the huge faux pas of both the US, vis a vis, the ISA, and China on several counts, what kind of message would an average bystander get?

China has worked on every trick in the trade to espouse to the world at large about their 'commitment' to uphold the letter and spirit of UNCLOS, and they have even had high-ranking officials to implant journal articles to secure the support of intelligentsia ${ }^{1}$. The P5, has a pick and choose policy and given that facts are stubborn things, they could get to decide what regulations are to be made binding and what should not be, and in such case scenarios, how can enforceability be a salient feature of UNCLOS ${ }^{2}$. An axiomatic

1 Ma, X. (2019, March 15). China and the UNCLOS: Practices and Policies. The Chinese Journal of Global Governance. https://brill.com/view/journals/cjgg/5/1/article-p1_1. $\mathrm{xml}$ ? language $=\mathrm{en}-$ the author was formerly the Deputy Director-General, Department of Treaty and Law, Ministry of Foreign Affairs of China

2 EastAsiaForum. Economics, Politics and Public Policy in East Asia and the Pacific. www.eastasiaforum.org - from July $11^{\text {th }}$ till date, China has only gone one to commit one heinous offence after another, and they have just gotten away scot-free, event after event, and as a matter of detail, no retributive action has been taken. Given that China is a permanent member of the UN Security Council coupled with the fact that a vast majority of nations in Sub-Saharan Africa, the Far East, and the Asian and Latin American regions literally pay obeisance to China due to its recently found economic prowess, even a resolution against its acts at the General Assembly would be an onerous proposition - several diplomats and activists groups have articulated perceptively in the matter and in fact, The Diplomat has dedicated numerous articles to bring this venality to the attention of humanity per se, but not even one concrete act against China's rowdiness has ensued. Whilst some scholars could cite a commentary on UNCLOS that runs thus - "Under UNCLOS, dispute settlement is compulsory and not optional as it is an integral part of the convention", the 
premise apropos the rule of law is enforceability and when it is characterized by its absence, or in its random applicability, then it ceases to be any worthwhile and binding rule of law.

\section{Results and Discussion}

UNCLOS suffers from the serious malaises, as has been explicitly mentioned, and though I have read the articles and monographs of scores of academicians and professionals who are highly proUNCLOS, it is quite obvious that they do not want to state the NOTICEABLE. For the record, I have candidly enunciated on the malaises, and for UNCLOS to really be called a legally binding instrument, it has to have the verve of impartial applicability - else, the words 'Legally binding' are just being masqueraded to suit the conveniences of jurists, diplomats and the powers that control the $\mathrm{UNO}^{1}$. Given that it is high time for the comity of nations to come to terms with certain core realities like that of the one ocean concept,

stark raving reality is entirely different and this should make any discerning researcher worth his salt, query the binding nature of UNCLOS - would it be a binding instrument only for lesser developed member states that do not have the clout in the international scheme of things? Yet another headline in an Indian tabloid: "China must honour legally binding UNCLOS verdict on the South China sea" - simply put, it was a good headline to read in the Economic Times dated July 9, 2021, and the corollary headline ought to read as "would China be made to honour the legally binding UNCLOS verdict, given that it is a signatory", and the emphatic answer would be in the negative, given the effeteness of previous UNCLOS verdicts, vis a vis, China. Additionally, China always plays a duplicitous game and as it has had its high-ranking officials write articles in their own journals - in effect, articles that praise UNCLOS but in reality they abuse the tenets of UNCLOS to suit their conveniences and their action would lead even a bystander to conclude that China is indeed part of the ' first amongst equals' group. Nothing but what they would get to choose would be binding for them.

1 The resolution (69/292 of the nineteenth of June, 2015, of the General Assembly) has been very well worded and the reality is there for all to decipher, including the scholars who base their findings entirely on book reports et al. UN Department of Economic and Social Affairs. Sustainable Development http://sustainabledevelopment.un.org - the Division of Ocean Affairs at the UNO has consummate professionals, perhaps the best in the world, but the core issue is at the level of certain non-cooperating members and the acts or the lack of it of some non-members. The moot point being that with reference to the research initiative three issues are of core signification. The aspect centric to the facile way in which offshore rigs can be blown up leading to humungous ecological destruction and given UNCLOS's ambivalence centric to declaring offshore rigs as installations, it makes matters very 
the faster we have a really legally binding and enforceable agreement that truly upholds the rule of law (that would be subscribed to by every nation that uses the seas and the oceans), the better it would be for the planet people and profits. The argumentation of the scholars have been centred on why the legally binding character of an international instrument should be separated from any consideration related to its practical implementation is in my considered opinion fallacious at its very core and this is an assertion that any discerning scholar would find it hard to buy. Given that they reiterate their position based on views like ... when an UNCLOS provision is violated and unenforceability ensues, it still would not matter as an internationally wrongful act has been registered and that via Article 1, ILC (International Law Commission), retributive action can be effectuated - whilst suggesting recourse to the ILC, they are themselves in effect providing for an endorsement that the UNCLOS has become a non-binding instrument per $\mathrm{se}^{1}$.

difficult to state the least. Coastal states will have to have the required powers to effectuate on ex ante preventive and safeguard measures.

1. Non-member states do not come under the purview of UNCLOS and thus far Article 1 of ILC has never ever been used - hence, it has to be recognized that the acts in the territorial waters or EEZ of a non-member state would be EQUALLY devastating from an ecological perspective, given the one ocean concept. UNCLOS would be, in effect, a totally non-binding instrument in such case scenarios.

2. Ejusdem Generis, in matters to do with the IMO, the designated global authority, the secretariat is a highly professionalized set-up but as the sombre irony via the non-cooperation of certain member states should have it, much-required rulings, vis a vis, widening the zones of safety and the need to declare rigs as installations have not been forthcoming and just as justice delayed is justice denied, must an event akin to the Deepwater Horizon be perpetuated by any of the rabid ideological outfits, for the IMO to effectuate on the required changes - until, then the prowess of the IMO is effete as they are unable to bind member states with regard to core and progressive issues - UNCLOS - http://www.imo.org

1 This entails the delinquent states' responsibility and liability with a number of consequences: e.g., economic, military use of UNSC instruments, etc. It could be argued that many of the provisions of UNCLOS are well implemented and enforced, and that it would be entirely possible to do so as it is a legally binding instrument. To provide for some illustrations, Article 73 (2) UNCLOS provides for the obligation of State Parties to promptly release vessel/crew arrested for fisheries violations in the EEZ and it is protected by the residual judicial mechanisms of ITLOS under Article 292 UNCLOS. Non-Contracting parties like Libya and Venezuela keep arresting foreign vessels in their EEZ and do not release 
As my research interests have been focussed apropos the safeguarding of deep-sea rigs and UNCLOS hasn't even differentiated between a vessel and an offshore rig - a grey area, in particular, would just make nothing enforceable in so far as deep-sea rigs go, and unless they are categorized by the Global Authority, namely IMO, as installations, coastal states will have no recourse with reference to safeguarding offshore rigs in the EEZ and beyond (Churchill, 2012).

Based on the aforementioned, it is amply clear that UNCLOS is indeed non-binding. Not a Universally Applicable Convention as some nations are not signatories and some other nations that are signatories are above the law. And everyone, everywhere has to realize that under the aegis of the one-ocean concept, when an offshore rig is devastated in one ocean area it would eventually destroy other ocean areas as well, even if the other ocean areas are part of the territorial sea of a non-member state.

\section{Conclusions}

Going forward, the challenge would be in building an effective maritime security regime, given the severe limitation of UNCLOS, and to be a part of the solution, it would be the onus of the comity of nations to evolve a consensus based on the cornerstones of equity and fair play. The uncertainty in the law of the sea would inevitably grow and increasingly State practice, across geographies, may well continue to diverge from the traditional views of the law. Given

them, simply because they are not obliged to do so. The contracting parties to UNCLOS do not have the choice, vis a vis, not releasing arrested vessels in a similar situational dictate. Even for a rather innocuous vertical like fishing, there is so much complication that could arise when a non-member is involved and as such for issues to do with offshore rigs, there would be much more calumny and confusion as member states which have recorded many registries, could have zilch presence in the offshore verticals et al. As an addendum, member states that are signatories, when they engage in blatant acts like what China has done repeatedly, could get away scot-free as enforceability has been very poor - in fact, there has not even been one instance wherein an UNCLOS violation has been dealt with via Article 1 of the ILC. UNCLOS is with certitude not flawless and like a host of other multilateral instruments, it was the result of a compromise, and the outcomes of such compromises have not always been successful in international jurisprudence. 
that states are increasingly under the influence of domestic politics and racial tensions, divergence per se is inevitable. As an indicative reference point, the United States would find it increasingly onerous to maintain its strict interpretation of navigational regimes and coastal state jurisdiction. The situational dictates would become increasingly dangerous in Asia, and in particular the South China Sea, would become a critical area, vis a vis, shaping the developments of the international law of the sea with reference to the future. There are several aspects of the convention that have to be re-examined and rewritten due to the severe differences and the acerbity that exists and given that the UNCLOS has been dubbed to be De Facto non-binding, should it have to be transformed into a De Jure binding agreement, the severe and crucial differences have to be sorted out. Until then, given the incremental nature of the acerbity, the De Facto non-binding nature would get to be literally cast in stone.

\section{REFERENCES}

Almond, R.G. (2017, May 24). U.S. Ratification of the Law of the Sea Convention. Measuring the raison d'Etat in the Trump era. The Diplomat. https:// thediplomat.com/2017/05/u-s-ratification-of-the-law-of-the-sea-convention/

Bandow, D. (1982). UNCLOS III: A Flawed Treaty. San Diego Law Review, 19, 3 , 475-492. https://digital.sandiego.edu/sdlr/vol19/iss3/5

Bateman, S. (2009, March 25). UNCLOS and Its Limitations as the Foundation for a Regional Maritime Security Regime. Korean Journal of Defense Analysis, 27-56. https://www.tandfonline.com/journals/rkjd20

Bromund, T.R., Carafano, J.J., \& Schaefer, B.D. (2018, June 4). 7 Reasons U.S. Should Not Ratify UN Convention on the Law of the Sea. The Heritage Foundation. https://www.heritage.org/global-politics/commentary/ 7-reasons-us-should-not-ratify-un-convention-the-law-the-sea

Chaudhury, D.R. (2021). China must honour legally binding UNCLOS verdict on South China Sea. The Economic Times. https://economictimes.indiatimes.com/ news/defence/china-must-honour-legally-binding-unclos-verdict-on-southchina-sea/articleshow/84257847.cms?from=mdr 
Churchill, R. (2012). The Persisting Problem of Non-compliance with the Law of Sea Convention: Disorder in the Oceans. The International Journal of Marine and Coastal Law, 27, 813-820.

EastAsiaForum. Economics, Politics and Public Policy in East Asia and the Pacific. https://www.eastasiaforum.org

Even without ratification, UNCLOS has already achieved binding customary international law status in the US. UNCLOS debate. https://www.unclosdebate.org/evidence/737/even-without-ratification-uncloshas-already-achieved-binding-customary-international

Guzman, A. The Consent Problem in International Law. Berkley Law School. https://escholarship.org/content/qt04x8x174/qt04x8x174_noSplash_ 5221402d70d7d0b5afbb467a7a464009.pdf

International Maritime Organization. http://www.imo.org

Kapoor, N. (2021, June 21). Russia's conduct in the South China Sea. ORF. Observer Research Foundation. https://www.orfonline.org/research/ russias-conduct-in-the-south-china-sea/

Karev, S. (1995). The Russian Federation and the UN Conference on the Law of the Sea. Proceedings of the Annual Meeting (American Society of International Law), 89, 455-458. http://www.jstor.org/stable/25658962

Koskenniemi, M. (2006). Fragmentation of International Law: Difficulties Arising From the Diversification and Expansion of International Law: Report of the Study Group of the International Law Commission, International Law Commission Fifty-eighth session (Geneva, 1 May - 9 June and 3 July 11 August). https://legal.un.org/ilc/documentation/english/a_cn4_1682.pdf

Ma, X. (2019, March 15). China and the UNCLOS: Practices and Policies. The Chinese Journal of Global Governance. https://brill.com/view/journals/ cjgg/5/1/article-p1_1.xml?language $=$ en

Mitchell, S., \& Owsiak, A. (2021). Judicialization of the Sea: Bargaining in the Shadow of UNCLOS. American Journal of International Law, 115(4), 579-621. https://doi.org/10.1017/ajil.2021.26

Schrepferman, W. (2019, October 31). Hypocri-sea: The United States'Failure to Join the UN Convention on the Law of the Sea. Harvard International Review. https://hir.harvard.edu/hypocri-sea-the-united-states-failure-to-join-the-unconvention-on-the-law-of-the-sea-2/

Some Irresponsible Nations Twisting Definition of UNCLOS: Rajnath Singh's Veiled Dig At China. (2021, November). Outlook. https://www.outlookindia.com/website/story/india-news-some-irresponsible- 
nations-twisting-definition-of-unclos-rajnath-singhs-veiled-dig-atchina/401932

The General Assembly. (2015, June 19). The resolution on Development of an international legally-binding instrument under the United Nations Convention on the Law of the Sea on the conservation and sustainable use of marine biological diversity of areas beyond national jurisdiction. (A/RES/69/292). https://documents-dds-ny.un.org/doc/UNDOC/GEN/N15/187/55/PDF/ N1518755.pdf?OpenElement

UN Department of Economic and Social Affairs. Sustainable Development. http://sustainabledevelopment.un.org

UNCLOS debate. http://www.unclosdebate.org

UNCLOS: fit for purpose in the 21st century? UK Parliament. https://committees.parliament.uk/work/1557/unclos-fit-for-purpose-inthe-21st-century/

United Nations. (1982, December 10). Convention on the Law of the Sea. www.un.org. https://www.un.org/depts/los/convention_agreements/texts/ unclos/unclos_e.pdf

Vaangal, K. (2021). Legal Status of Offshore (Deep-Water) Oil Rigs: Coastal State Jurisdiction and Countering Oil Spills Threats. Lex Portus, 7(5), 42-68. https://doi.org/10.26886/2524-101X.7.5.2021.3

Van Deutekom, J. (2016, July 21). UNCLOS, undone by China? Gateway House. https://www.gatewayhouse.in/unclos-undone-by-china/

Ваангал К. Перегляд UNCLOS: недотримання та можливість примусового виконання. - Стаття.

У статті досліджується ефективність UNCLOS і пояснюється, чому вона де-юре не $\epsilon$ зобов'язуючою угодою, а де-факто - угодою незобов'язуючою. Наголошується, що невизначеність у морському праві неминуче зростатиме, і практика держав у всіх географічних регіонах цілковито може, як і раніше, розходитися 3 традиційними поглядами на право. Враховуючи, що держави усе більше перебувають під впливом внутрішньої політики та расової напруженості, розбіжність сама по собі $є$ неминучою, і вкрай необхідно, щоб спільнота націй об'єднала свої дії щодо перегляду UNCLOS і після цього уклала угоду, яка буде працездатною. Необхідність переписати цей договір вимагатиме великих зусиль та співпраці усіх держав i, безсумнівно, потребуватиме егалітарних підходів.

Ключові слова: морське право, Конституція для океанів, морська юриспруденція, концепція єдиного океану, обов'язковий характер, тлумачення UNCLOS, міжнародне право, США, Китай. 
Ваангал К. Пересмотр UNCLOS: несоблюдение и возможность принудительного исполнения. - Статья.

В статье исследуется эффективность UNCLOS и объясняется, почему она де-юре не является обязывающим соглашением, а де-факто - соглашением необязывающим. Отмечается, что неопределенность в морском праве неизбежно будет расти, и практика государств во всех географических регионах вполне может по-прежнему расходиться с традиционными взглядами на право. Учитывая, что государства все больше находятся под влиянием внутренней политики и расовой напряженности, расхождение само по себе неизбежно, и крайне необходимо, чтобы сообщество наций объединило свои действия относительно пересмотра UNCLOS и после этого заключило соглашение, которое будет работоспособным. Необходимость переписать этот договор потребует больших усилий и сотрудничества всех государств и, несомненно, потребует эгалитарных подходов.

Ключевые слова: морское право, Конституция для океанов, морская юриспруденция, концепция единого океана, обязательный характер, толкование UNCLOS, международное право, США, Китай. 